animal geography, has given an informed basis for a judgment on Wallace's place amongst nineteenth-century biologists. Her book should send many readers back to the sources to realise and enjoy Wallace's fertility of mind. The chapters on geographical distribution of animals and on island life should dispel any doubts as to Wallace's greatness. In 1880 it was no commonplace to insist on an ecological outlook. Wallace wrote of the " complete interdependence of organic and inorganic nature...". Wallace's mind was quick, intuitive, perceptive, but the drive of experimental verification was absent. He wrote about the significance of Douglas Spalding's early work on what is now termed imprinting in young chicks and ducklingsnot mentioned by Wilma George. He possessed this primary asset of perceiving the significant, but he was not dogged in following the track. To readers of ORYX, the story of collectors of specimens of more than a hundred years ago has a special meaning. Museums had to be stocked for the increase of knowledge ; but Wallace's collections were already going to rich private collectors, the forerunners of the spoliators of today. Wallace had to reach his ambition of travel and scientific discovery the hard way. Money was short ; he, like Darwin, was often ill, and a dramatic ship-wreck ruined many of his spoils. Darwin was well-off, and the chance to travel the world as naturalist came unasked. But it was the ordered use of his opportunities that counted.

NORA BARLOW

\title{
The Life of Birds. By Joel Carl Welty. Constable, 84s.
}

In his opening paragraphs the author, a Professor of Zoology at Beloit College, Wisconsin, U.S.A., informs his readers that his book is directed to the general student, and not towards the specialist. Even if that be granted, a survey of the twenty-three chapter-headings should convince the specialist that he can ill afford to neglect its pages, for here, gathered under one cover, is an encyclopaedia of specialised knowledge, covering, as the title claims, the life of birds. In addition to discussing the more ordinary subjects such as social behaviour, territory, nests, eggs, incubation and so on, Dr. Welty has much to tell us concerning courtship, ecology, geography, migration, orientation and evolution, all of which and many other subjects besides, he deals with in an agreably lucid manner, shunning, as he is careful to state, all technicalities which can be avoided. The result is a thoroughly readable compilation. At the end of the book he sets out in alphabetical sequence the names of those authors to whose writings he is particularly indebted, and when we consider that "about 800 seemed important enough to merit special mention ", the extent of his reading will be understood. More than on any other author Dr. Welty has relied upon that remarkable work Aves by Professor Erwin Stresemann, an outstanding contribution to ornithological science, and one that is all too little known in Great Britain. It is written in German which is undoubtedly the cause.

In his preface the author deplores that-in America-societies for bird study are relegated to a lower caste than those devoted to the study of fishes, reptiles, mammals, insects and even microscopic protozoa ; for years " bird researchers" have been treated as second-rate scientists " not worthy of the rank in academic peck order that is accorded even to a specialist in tapeworms." That to a great extent was true in our own country, but those days are fast drawing to a close and books such as Aves to which Dr. Welty has paid such high tribute, and now his own more popular treatise, go far to prove that ornithologists, to whatever country they belong, will soon be in the very front rank in zoological science, if indeed they are not already there. 
The many line drawings of birds, maps and other text-figures, all exceptionally clear, are the work of a talented artist, Norman Tolson, who regrettably did not live to see the book - and his fine handiwork-produced. The numerous photographs are of high standard, and we note with interest that Eric Hosking is responsible for many of the best.

DAVID BANNERMAN

\section{Our Crowded Planet. Edited by Fairfield Osborn. Allen and Unwin, $21 s$.}

Fairfield Osborn has gathered together over a score of distinguished biologists, historians, economists and others, and each has contributed a chapter to this symposium, sponsored by the Conservation Foundation. Expectedly the quality varies but, integrated, this small volume of 192 pages is excellent and should arouse the interest of many. A chapter a week as a basis for a sixth form discussion class would be an excellent use for it. It is informative, educative and authoritative, even if sometimes a trifle dry in the presentation. Those interested in conservation may be, and certainly should be, jolted into greater recognition that it is not alone the personal folly of mankind which jeopardises the continued existence of other creatures, but the inevitable increase of man-pressure as human population doubles and doubles again.

An introduction by the editor precedes five sections whose titles well illustrate the scope of the whole. They are :-Population Pressures on Man's Natural Environment (Frank Darling has an excellent essay here); Population Pressures on Economic and Political Trends (Eugene Black and Solly Zuckerman among others); Population Pressures in Specific Areas (Walter Lowdermilk and others); The Population Problem and Religion ; Population Pressures on Morals and Ethics (André Maurois and Julian Huxley).

The integrative powers of Julian Huxley, in his terminal essay, combined with his high distinction in the sheer art of writing, make his contribution pre-eminent. "We must look at the question of population increase in the light of the new vision of human destiny which human science and learning has revealed to us.... We must also look at it in the light of the appalling possibilities for evil and misery that still remain for human life in the future.... I would say that this vision, of the possibilities of wonder and more fruitful fulfilment on the one hand as against frustration and increasing misery and regimentation on the other, are the twentieth-century equivalents of the traditional Christian view of salvation as against damnation".

\section{COLIN BERTRAM}

\section{The Deer of Great Britain and Ireland. By G. Kenneth Whitehead. Routledge and Kegan Paul, $\$ 66 \mathrm{~s}$.}

For some years after it had been written, the manuscript of this book proved too formidable a proposition for the publishers. Kenneth Whitehead had spared no effort in its early preparation, and had gathered together a vast assemblage of facts resulting from his researches on the distribution of deer in Great Britain and Ireland. Its welcome appearance at the present time has at last made this mine of information available to the many people now increasingly concerned with the conservation and control of deer, as well as the growing number of those who have taken up the study of deer for the interest and pleasure it affords. The publishers are to be congratulated in bringing out so valuable a work of reference. 